\title{
Deforestation caused abrupt shift in Great Lakes nitrogen cycle
}

DOI:

10.1002/Ino.11428

\section{Document Version}

Accepted author manuscript

Link to publication record in Manchester Research Explorer

\section{Citation for published version (APA):}

Guiry, E. J., Buckley, M., Orchard, T. J., Hawkins, A. L., Needshowarth, S., Holm, E., \& Szpak, P. (2020).

Deforestation caused abrupt shift in Great Lakes nitrogen cycle. Limnology and Oceanography.

https://doi.org/10.1002//no.11428

\section{Published in:}

Limnology and Oceanography

\section{Citing this paper}

Please note that where the full-text provided on Manchester Research Explorer is the Author Accepted Manuscript or Proof version this may differ from the final Published version. If citing, it is advised that you check and use the publisher's definitive version.

\section{General rights}

Copyright and moral rights for the publications made accessible in the Research Explorer are retained by the authors and/or other copyright owners and it is a condition of accessing publications that users recognise and abide by the legal requirements associated with these rights.

\section{Takedown policy}

If you believe that this document breaches copyright please refer to the University of Manchester's Takedown Procedures [http://man.ac.uk/04Y6Bo] or contact uml.scholarlycommunications@manchester.ac.uk providing relevant details, so we can investigate your claim.

\section{OPEN ACCESS}


${ }^{* 1,2}$ Eric J. Guiry, ${ }^{3}$ Michael Buckley, ${ }^{4}$ Trevor J. Orchard, ${ }^{5}$ Alicia L. Hawkins, ${ }^{6,78}$ Suzanne NeedsHowarth, ${ }^{9}$ Erling Holm, ${ }^{1}$ Paul Szpak

\footnotetext{
${ }^{1}$ Department of Anthropology, Trent University, 1600 West Bank Dr., Peterborough, ON, K9L 0G2, Canada (eguiry@lakeheadu.ca; paulszpak@trentu.ca)

${ }^{2}$ School of Archaeology and Ancient History, University of Leicester, Mayor's Walk, Leicester, LE1 7RH, United Kingdom

${ }^{3}$ Department of Earth and Environmental Sciences, Manchester Institute of Biotechnology, The University of Manchester, 131 Princess Street, Manchester M1 7DN, United Kingdom (m.buckley@ manchester.ac.uk)

${ }^{4}$ Department of Anthropology, University of Toronto Mississauga, 3359 Mississauga Road, Mississauga, ON L5L 1C6, Canada (trevor.orchard@utoronto.ca)

${ }^{5}$ Archaeology program, School of the Environment, Laurentian University, 935 Ramsey Lake Rd., Sudbury, ON P3E 2C6, Canada (ahawkins@laurentian.ca)

${ }^{6}$ Perca Zooarchaeological Research, Toronto, Canada (suzanne.needs.howarth@utoronto.ca)

${ }^{7}$ The Archaeology Centre, University of Toronto, 19 Russell Street, Toronto, ON M5S 2S2, Canada

${ }^{8}$ Trent University Archaeological Research Centre, 1600 West Bank Dr., Peterborough, ON K9L 0G2, Canada

${ }^{9}$ Department of Natural History, Royal Ontario Museum, 100 Queen's Park, Toronto, ON M5S 2C6, Canada (erlingh@rom.on.ca)
}

\section{$\underline{\text { Abstract }}$}

Despite the longstanding significance of North America's Great Lakes, little is known about their pre-industrial ecology. Here, we report on when and how humans first became a main driver of Lake Ontario's nutrient dynamics. Nitrogen isotope analyses of archaeological fish show that, prior to the 1830s, Lake Ontario's nitrogen cycle and the trophic ecology of its top predators had remained stable for at least 800 years, despite Indigenous and historical European agricultural land management across the region. An abrupt shift in the nitrogen isotope composition of Lake Ontario's fish community is evident in the early to mid-nineteenth century and reflects the initiation of industrial-scale forest clearance. These data show how the nitrogenous nutrient regimes of even the world's largest freshwater ecosystems can be highly sensitive to short-term watershed forest cover disturbances and indicate a profound shift in the relationship between humans and their environment.

\section{$\underline{\text { Keywords }}$}

Historical Ecology, Archaeology, Great Lakes, Nitrogen Cycle, Fish, Deforestation 
Throughout the twentieth century, increased anthropogenic contributions of reactive nitrogen to freshwater environments have profoundly altered aquatic biogeochemical cycles and broader nutrient dynamics, resulting in widespread ecosystem dysfunction, loss of biodiversity, and degraded water quality (Smith and Schindler 2009). While numerous studies have documented how increasing anthropogenic nitrogen inputs are incorporated into aquatic food webs, promoting cultural eutrophication and altering trophic dynamics in the recent past (Schindler, et

al. 2006), less consideration has been given to how historical and preindustrial populations have impacted aquatic ecosystems. In the context of recent debate about the timing of the origins of the Anthropocene (Lewis and Maslin 2015), in which past societies are considered as potential architects of the first broad-scale environmental changes, the role of humans as drivers of biogeochemical processes such as the nitrogen cycle is becoming increasingly important (Guiry, et al. 2018; Hadley, et al. 2010; Kintigh, et al. 2014).

For conservation and restoration efforts in freshwater ecosystems, where cultural eutrophication caused by increased nutrient loading poses one of the most significant threats globally (Smith and Schindler 2009), long-term retrospectives that document when and how human activities first began to alter natural ecosystem processes, and the nitrogen cycle in particular, could provide a valuable framework for evaluating which modern human activities pose the greatest risks (Canfield, et al. 2010; Humphries and Winemiller 2009). Paleolimnological proxy indicators based on the physical, biological, chemical, and isotopic compositions of sediments have long been used to establish trends in past aquatic productivity and water quality (Beeton 1965; Hodell and Schelske 1998; Jeffers, et al. 2015; Schelske, et al. 1983), but, because of potential taphonomic issues (Anderson 2014; Lu, et al. 2014) and because these approaches 
usually do not incorporate consumers, they are unable to measure the direct impacts of anthropogenic nitrogen loading on nutrient dynamics in the wider biotic community (e.g., invertebrates, fish, birds; although for a growing literature on invertebrate analyses see Anas, et al. 2019; Frossard, et al. 2014; Perga 2010; Perga, et al. 2010; Schilder, et al. 2017; van Hardenbroek, et al. 2010). Moreover, while many studies using isotopic analyses of museumarchived vertebrate tissues have been able to make important contributions to understanding how biotic communities have responded to human-caused environmental change during the twentieth century (Fera, et al. 2017), a lack of suitable specimens from early historical and pre-industrial time periods has, in most cases, prevented analyses of longer-term environmental variation in vertebrate taxa (Szpak, et al. 2018). In this context, stable nitrogen isotope and other analyses of ancient fish remains from archaeological repositories can provide an invaluable opportunity to gain direct insight into how food web and nutrient dynamics within pre-industrial ecosystems functioned and responded to impacts from human activities at varying temporal and spatial scales (Guiry, et al. 2016a).

Using isotopic compositions of fish bone or scales has some interpretive advantages relative to more commonly analyzed materials, such as bulk sedimentary organic matter, because fish stable nitrogen isotope composition is linked firmly with a known ecological point (i.e. a particular species with well-understood ecology and trophic affinity) and spatiotemporal framework (Trueman and Moore 2007) and can be easily parsed to remove diagenetically altered samples using robust quality-control criteria (DeNiro 1985; Szpak 2011). This is important because, in contrast to analyses of bulk sedimentary organic matter, which is composed of a spatially, temporally, and biologically heterogeneous mixture of sources of detritus (Lu, et al. 2014), with fish bone or scales, the ability to compare "taxonomically anchored" isotopic patterns across 
different parts of a food web will enable much higher-resolution interpretations of environmental change at both the level of nutrient dynamics and the level of broader food web structures. Moreover, with respect to measuring the isotopic compositions of ancient organic materials, the ability to purify collagen extracted from bone (through pretreatment steps outlined below) and assess the extent to which its constituent carbon and nitrogen are biogenic (e.g., using wellestablished and precise C: $\mathrm{N}_{\text {Atomic }}$ criteria (DeNiro 1985; Szpak 2011) provides an additional advantage relative to other important paleontological materials (e.g., chitinous remains from sub fossil invertebrates; Anas, et al. 2019) and makes bone and scale collagen particularly well suited for inter-site comparisons of isotopic variation in biota across time and space. Moreover, because collagen from bones and scales is constructed and remodeled slowly throughout the life of an organism, the isotopic composition of collagen can provide a lifetime average record of dietary intake and environmental conditions that is less susceptible to seasonal or short-term idiosyncratic shifts in behavior (Hobson and Clark 1992). Bone collagen is therefore well suited for reconstructing long-term trends in biology and ecology (Bump, et al. 2007) and can provide an additional perspective with potential to complement and build on the success of previous, well-established paleolimnological proxy indicators (e.g., physical, chemical, and isotopic compositions of sediments and invertebrates; Beeton 1965; Hodell and Schelske 1998; Jeffers, et al. 2015; Perga 2010; Schelske, et al. 1983).

We use stable nitrogen isotope compositions and peptide mass fingerprinting (Zooarchaeology by Mass Spectrometry, hereafter, ZooMS) of late Holocene (900-2015 CE) fish bone collagen from a large number of sites associated with Lake Ontario (Figure 1), the most easterly of the Laurentian Great Lakes (hereafter, Great Lakes), to document long-term trends in regional biogeochemical cycles. Results show that, in comparison with the industrial era, the nitrogen 
106

107

108

109

110

111

112

113

114

115

116

117

cycle and trophic structure of this Great Lakes ecosystem remained remarkably stable until the 1830s, despite millennia of Indigenous agricultural and other land management, decades of European settlement, and climatic fluctuations. After this time, increased N-loading from forestry- and agriculture-induced soil erosion caused an unprecedented and abrupt bottom-up shift throughout the entire aquatic ecosystem of Lake Ontario.

\section{Context}

With more than $20 \%$ of the world's surface freshwater, North America's Great Lakes are of tremendous ecological, economic, and social interest (Sterner, et al. 2017). Since monitoring programs began, the Great Lakes have experienced significant ecological and chemical changes in response to pollution, hydrological controls, and species invasion (Allan, et al. 2013; Stewart, et al. 2016). Paleolimnological studies show that recent industrial activities have had profound impacts on Great Lakes productivity (Beeton 1965; Hodell and Schelske 1998; Jeffers, et al. 2015; Meyers 2003; Schelske and Hodell 1991b; Schelske and Hodell 1995; Schelske, et al. 1988; Schelske, et al. 1983), especially through increased phosphorus and nitrogen loading that led to eutrophication of Lake Ontario and Lake Erie by the twentieth century (Hodell and Schelske 1998; Lu, et al. 2010). With respect to nutrient dynamics, particularly the nitrogen cycle, which plays a vital role in primary production in naturally oligotrophic ecosystems such as Lake Ontario (Lean and Knowles 1987; Leggett, et al. 2000), the extent to which these changes represent a departure from longer-term trends in broader food web structure and nutrient dynamics remains unclear (Sterner, et al. 2017; Supplementary Information [SI] 1). But this extent could be determined through isotopic reconstructions of past nutrient and food web dynamics using historical or archaeological fish specimens, as these can provide a complementary isotopic record for ancient environmental variation. 
Human activities have modified the cycling of nitrogen in aquatic environments across the globe, contributing to the ongoing threat of cultural eutrophication (Gruber and Galloway 2008; Smith and Schindler 2009). The majority of these impacts occur when anthropogenic nitrogen inputs and/or chemical or physical changes to an environment alter the conditions regulating the nitrogen cycle, thereby disrupting the flow of nitrogenous nutrients through an ecosystem (Kendall, et al. 2007). Modeling how nitrogen moves into and through aquatic ecosystems is, therefore, of considerable importance for conservation efforts seeking to restore heavily impacted watersheds (Denk, et al. 2017). With respect to broad-scale human impacts, such factors as climate change, acid rain, nutrient loading, and invasive species introductions can significantly alter the biogeochemical processes that balance an aquatic ecosystem's nitrogen cycle and often, in turn, cause detectable changes in the isotopic composition of nitrogen pools that are available to support aquatic life (Anderson and Cabana 2005; Botrel, et al. 2014; Lake, et al. 2001). Stable nitrogen isotopic compositions of consumer tissues show a stepwise increase, by roughly 3-4\%o, in $\delta^{15} \mathrm{~N}$ values with each trophic level step up in a food web and have therefore traditionally provided a powerful indicator for food web interactions in ecology and archaeology (Post 2002). However, because any impact on the $\delta^{15} \mathrm{~N}$ of aquatic nitrogen pools at the base of a food web (i.e., in various pools of dissolved inorganic nitrogen [DIN]) is passed up the trophic ladder to producers (phytoplankton) and their consumers (invertebrates and fish), isotopic analyses of tissues from aquatic producers and consumers can also serve as a highly integrative indicator for anthropogenic impacts on nutrient dynamics, in addition to food web structure, in aquatic environments (Hoffman, et al. 2012; Morrissey, et al. 2013). While a majority of isotopic research has approached the question of changing freshwater nutrient dynamics through analyses of sedimentary organic matter (e.g., Dubois, et al. 2018; Talbot 
152 2001), a growing number of studies are demonstrating that $\delta^{15} \mathrm{~N}$ compositions of invertebrates

153 and fish can provide a highly sensitive record for environmental change (e.g., Anas, et al. 2019;

154 Fera, et al. 2017; Lumb and Johnson 2012; Perga, et al. 2010).

155 The natural abundance of ${ }^{15} \mathrm{~N}$ in DIN is largely controlled by three factors (for reviews see,

156 Finlay and Kendall 2007; Guiry 2019; Kendall 1998; Kendall, et al. 2007; Talbot 2001):

157 productivity (Hodell and Schelske 1998; Schelske and Hodell 1991a), environmental conditions

158 (temperature, oxygenation, and pH; Finlay and Kendall 2007; Knowles 1982), and nitrogen

159 inputs (quantity and isotopic composition; Heaton 1986; Lake, et al. 2001). These factors are

160 necessarily interrelated because, for instance, increasing the input of reactive nitrogen can

161 increase productivity, and this can affect environmental conditions that regulate other parts of the

162 nitrogen cycle (Finlay and Kendall 2007). Moreover, nitrogen-limitation rates can influence

163 plankton community composition, which is an integral component of determining the presence

164 of nitrogen-fixing bacteria ( $\mathrm{Gu} 2009)$ that can further modify the isotopic composition of an

165 aquatic ecosystem by introducing isotopically distinctive atmospheric nitrogen. Human activity

166 should affect those factors controlling the nitrogen cycle and its isotopic composition (for review

167 see Guiry 2019) by: 1) contributing reactive nitrogen (i.e., through inputs directly from sewage,

168 agriculture, and soil erosion - typically, but not always, leading to elevated biota $\delta^{15} \mathrm{~N}$ (Anderson

169 and Cabana 2005; Morrissey, et al. 2013)), which itself leads to increasing productivity (creating

170 greater nitrogen demand and thereby possibly promoting the importance of $\mathrm{N}$-fixing algae -

171 leading to higher and lower biota $\delta^{15} \mathrm{~N}$, respectively( $\mathrm{Gu} 2009$; Pennock, et al. 1996)), and 2)

172 changing chemical conditions, such as $\mathrm{pH}$ and oxygen levels, that regulate transformations

173 between important forms of reactive nitrogen (altering the dynamics for nitrification and 
174 denitrification - with potential to push biota $\delta^{15} \mathrm{~N}$ higher or lower (Collister and Hayes 1991; 175 Sebilo, et al. 2006)).

176 With the longest history of European and Indigenous agricultural land management and 177 settlement among the Great Lakes, Lake Ontario and its watershed are an ideal context in which 178 to investigate how large-scale human activities can impact major freshwater environments over 179 time (Hodell and Schelske 1998). Because Lake Ontario receives a large amount of its water 180 from land runoff, it is particularly sensitive to broader ecological processes and human 181 disturbances occurring across the watershed, particularly in terrestrial and riparian zones. 182 Moreover, the significant and highly visible environmental degradation of Lake Ontario's watershed throughout the twentieth century, as well as its close proximity to major population centers, has spurred considerable research into its ecological structure (e.g., Bogue 2001; Estepp and Reavie 2015; Meyers 2003; Stewart, et al. 2016). For this reason, the lake has a relatively well-documented ecological and biogeochemical history, with numerous isotopic studies of modern fish identifying recent trends in community structure, trophic dynamics, and energy flows (Colborne, et al. 2016; Fera, et al. 2017; Kiriluk, et al. 1995; Lumb and Johnson 2012; Rush, et al. 2012; Yuille, et al. 2015). The longest-term of these studies, however, only offers a 70-year retrospective, one that postdates intensification of European settlement of Lake Ontario's watershed by more than 150 years.

While a number of important isotopic studies have helped to document longer-term variability in Lake Ontario's nitrogenous nutrient dynamics (SI 1), these have focused on isotopic compositions of organic matter in lake sediments rather than specific taxa. With respect to the last millennium, the timeframe over which human land management would have intensified, most $(95 \%)$ of these analyses focus on the period after the mid-nineteenth century and show 
197 substantial change in the nitrogen isotopic composition of organic matter settling out of Lake

198 Ontario's water column (SI 1; Figure S1, Figure 2; Hodell and Schelske 1998; McFadden, et al.

199 2004). Only a small fraction (5\%; $n=8$ of 178) of analyses cover the early historical period

200 (1600s-1850 CE), when European activities would have started impacting the region, and pre-

201 contact period, when Indigenous farming and other land management activities were accelerating

202 across the watershed (i.e., starting with the Late Woodland, c. 900 CE). Moreover, only one lake

203 sediment isotopic dataset spans both time frames and is not consistent with the others (SI 1,

204 Figure 2). While these data provide an invaluable macro-scale perspective on general patterns in

205 nutrient dynamics in Lake Ontario, they cannot be used to assess the consequences of shifting

206 nitrogenous nutrient regimes for the broader food web (invertebrates and fish). Moreover, the

207 coarse temporal resolution of the lake sediment isotopic record prior to 1850 prevents detailed

208 analyses of when the human activities began to impact the nitrogen cycle and to what extent

209 early historical and Indigenous activities may have been important drivers for change. In this

210 context, isotopic analyses of archaeological fish can provide a complementary line of evidence

211 for nutrient dynamics and food web structure.

$212 \quad$ Materials and methods

213 Sample description: Sampling focused on three taxa in the family Salmonidae: lake trout 214 (Salvelinus namaycush; $n=222$ ), Atlantic salmon (Salmo salar; $n=158$ ), and whitefishes 215 (Coregonus spp.; primarily C. clupeaformis and C. artedi, see below; $n=277$; SI 2, Table S1).

216 These taxa were selected to provide a highly integrated record of changes to Lake Ontario's 217 nitrogen cycle and trophic structure. The upper trophic position and longer lifespan (5-15 years) 218 as well as pelagic foraging and highly mobile behavior of these species means that their diets 219 will incorporate a broad range of resources from across the lake (Fera, et al. 2017; Guiry, et al. 
2016a; Rush, et al. 2012), providing a time-averaged perspective on processes affecting the nitrogen cycle at a lake-wide, multi-seasonal scale. A comparison of isotopic variation among three taxa, each with a different behavioral strategy and trophic position (Fera, et al. 2017; Holm, et al. 2009; Mumby, et al. 2018), should make isotopic trends associated with dietary shifts at the species level (as opposed to changes at the base of the food web) clearly discernible and, therefore, these data also give a long-term perspective on the stability of Lake Ontario's food web structure.

With the exception of nine Atlantic salmon samples, all archaeological specimens are from sites within the Lake Ontario watershed. As Lake Ontario is the only known source of Atlantic salmon, specimens from this species at sites outside the watershed were also included because they represent individuals originating from Lake Ontario. Where possible, archaeological fish bone specimens were selected based on minimum number of individual counts per archaeological context in order to avoid sampling the same individual multiple times. For all species, archaeological sampling efforts targeted bone specimens from adult-sized fish in order to exclude juveniles, who may feed at a lower trophic level. All specimens were examined by one or more of three zooarchaeologists (S.N.-H., A.H., T.O.) with specific expertise in the identification through comparative osteology of archaeological fish bones from relevant taxa in the Great Lakes region (Hawkins, et al. 2019). The archaeological samples are largely derived from fish vertebra, because they are more ubiquitous than fish cranial and pectoral girdle bones in the archaeological collections. Zooarchaeologists determined species for each specimen where possible, based on clear morphological differences between taxa. Due to overlaps in osteology and the possibility of hybrids, morphological examination of Coregonus vertebrae and many Coregonus cranial and pectoral girdle bones cannot be confidently used to assign species-level 
243 identification in the Lake Ontario watershed. However, of the five Coregonus species that are 244 native to Lake Ontario, only two, lake whitefish (C. clupeaformis) and cisco (C. artedi), inhabit 245 waters shallow enough to have been broadly accessible using fishing technologies (birch bark 246 canoes and gill nets) available in the pre-contact past, and it is therefore highly likely that 247 archaeological Coregonus of that time are composed of these taxa. Some bones in the genera 248 Salvelinus and Salmo are also morphologically similar to each other, resulting in additional 249 higher-level taxonomic identifications (including to Salmo salar/Salvelinus namaycush and 250 Salmonidae). In cases where a species-level taxonomic identification was not achieved with a 251 high degree of certainty, we undertook ZooMS analyses $(n=292)$ to confirm identifications, 252 comparing the archaeological samples with reference sequences we generated for S. salar, S. 253 namaycush, brook trout (Salvelinus fontinalis), round whitefish (Prosopium cylindraceum), C. 254 clupeaformis, and C. artedi (Supporting Information 4 Table S1).

255 Dating for pre-contact specimens is based on published (SI 2, Table S2) radiocarbon dates, 256 ceramic seriations, and reconstructed village occupation sequences (e.g., Williamson 2014), to occupations within 100-year bins. Excellent chronological control for data from Indigenous 258 archaeological sites reflects the highly standardized lifecycle in which settlements were built, 259 occupied, decommissioned, and left behind in favor of relocation every 10-30 years (Warrick 260 2008). The relative dearth of data from the seventeenth and eighteenth centuries reflects changes 261 in Indigenous settlement patterns during this period. Reduced sample sizes in the nineteenth 262 century reflect lower frequencies for fish bone at Euro-Canadian archaeological sites. Historical 263 fish scale samples of adult specimens of known date were taken from museum-archived 264 collections with assistance from an Ontario fish identification expert (E.H.). Analyses of scales 265 from museum-archived Coregonus specimens include both $C$. clupeaformis and C. artedi 
because: 1) these two species likely account for the majority of archaeological specimens and will therefore be directly comparable; and 2), based on $\delta^{15} \mathrm{~N}$ values, they appear to have fed at the same trophic level in early twentieth-century Lake Ontario. For data sourced from the literature ( $n=834$; (Colborne, et al. 2016; Fera, et al. 2017; Guiry, et al. 2016a; Kiriluk, et al. 1995; Rush, et al. 2012; van der Merwe, et al. 2003; Yuille, et al. 2015)), fork length, when available, was used to exclude juveniles, which may feed at a lower trophic level.

Sample preparation: Samples weighing between 30 and $300 \mathrm{mg}$ were cut from bone specimens, residual bone lipids were removed with a series of 2:1 chloroform:methanol ultrasonic baths (solution refreshed every 10 minutes until visible signs of reaction ceased), and the samples were then left to air dry (Guiry, et al. 2016b). Bone samples were then demineralized in $0.5 \mathrm{M}$ hydrochloric acid $(\mathrm{HCl})$ for several days at $4{ }^{\circ} \mathrm{C}$ and then rinsed to neutrality in Milli-Q water. Humic acids and other base soluble contaminants from the burial environment were removed from demineralized bone samples with successive treatments in $0.1 \mathrm{M}$ sodium hydroxide in an ultrasonic bath (solution refreshed every 15 minutes until visible signs of reactions ceased) and then rinsed to neutrality in Milli-Q water (Szpak, et al. 2017a). Bone samples were then solubilized in $10^{-3} \mathrm{M} \mathrm{HCl}$ in an oven at $65^{\circ} \mathrm{C}$ for 48 hours. The resulting solutions were centrifuged, after which the solubilized collagen fraction was transferred to a new tube and then frozen and lyophilized.

The protein fraction of fish scale is also composed primarily of collagen, which is compositionally and isotopically comparable to fish bone collagen (Guiry, et al. 2016a; Trueman and Moore 2007). Fish scales samples underwent a succession of three rinses in Milli-Q water in an ultrasonic bath for five minutes each (Guiry, et al. 2016a). Scale samples were then soaked for five minutes in $1.0 \mathrm{M} \mathrm{HCl}$ in an ultrasonic bath to remove the mineral phase of the scale's 
external plate as well as any microscopic debris that may have become adhered to the external surfaces of the fish specimens during preservation and storage. Scale samples were then rinsed to neutrality in Milli-Q water in an ultrasonic bath and left to air dry. The historical fish specimens had been preserved using formalin fixation and then stored in ethanol. While this form of preservation is known to introduce small quantities of carbon, which can slightly alter the stable carbon isotope composition of biological tissues, formalin and ethanol provide no new sources of nitrogen and therefore have a minimal influence the nitrogen isotopic composition of preserved fish scales. To confirm this, we also compared the percent carbon-to-nitrogen ratio $(\mathrm{C}: \mathrm{N})$ of historical scales with that of modern fish scales (see below; (Szpak 2011)) to establish that diagenetic nitrogen is not present.

Isotopic analyses: The stable nitrogen isotope composition as well as percent carbon and nitrogen were measured on $0.5 \mathrm{mg}$ samples of bone and scale collagen using an Elementar Vario MICRO cube elemental analyzer coupled via continuous flow to an Isoprime isotope ratio mass spectrometer in the Archaeology Chemistry Laboratory at the University of British Columbia, Canada. Duplicate or triplicate analyses were performed on $14 \%$ of samples. For a full account of procedures used for calibration of isotopic values as well as isotopic uncertainty calculations see SI 3. Analytical uncertainty for $\delta^{15} \mathrm{~N}$ measurements was $+0.20 \%$ (Szpak, et al. 2017b; SI 3). The following data quality criteria were applied for establishing the integrity of $\delta^{15} \mathrm{~N}$ measurements from bone and scale collagen (DeNiro 1985): 1) \% carbon and \% nitrogen values above $13 \%$ and $4.8 \%$, respectively; and 2) atomic C:N values falling between 2.9 and 3.6.

ZooMS analyses: Collagen was rehydrated with approximately $100 \mu \mathrm{L} 50 \mathrm{mM}$ ammonium bicarbonate per milligram and each digested with $0.4 \mu \mathrm{g}$ sequencing grade trypsin (Promega, UK) overnight at $37^{\circ} \mathrm{C}$. Initial attempts were made at directly spotting these digests through 
312 dilution in $0.1 \%$ trifluoroacetic acid (TFA; Buckley, et al. 2018), but many required ZipTip

313 purification with C18 solid phase extraction and rehydration in 0.1\% TFA (Buckley, et al. 2009).

314 Samples were spotted onto a stainless-steel Matrix Assisted Laser Desorption Ionization

315 (MALDI) target plate with equal volume of $10 \mathrm{mg} / \mathrm{mL}$ alpha-cyano hydroxycinnamic acid in

$31650 \%$ acetonitrile/0.1\% TFA and allowed to air dry. Dried spots were then analyzed using a

317 Bruker Ultraflex II MALDI mass spectrometer over the $\mathrm{m} / \mathrm{z}$ range 700-3700 with up to 2,000

318 laser acquisitions for each sample. Peptide mass fingerprints were then compared with those of

319 standard reference material via the identification of genus- or species-specific biomarkers (SI 4).

320 Statistical analyses: For statistical comparisons of fish $\delta^{15} \mathrm{~N}$ values, each taxon (i.e., lake trout,

321 Atlantic salmon, whitefishes) was compared separately by time periods binned by 100 (pre-1925

$322 \mathrm{CE}$ ) and 25 (post-1925 to present) year groups (SI 5, Table S1) using PAST version 3.22. Bin

323 timeframes were selected with a view to maximizing sample size per bin. To assess whether fish

$324 \delta^{15} \mathrm{~N}$ values changed over time we first compared pre-1800 bins to one another to establish

325 whether significant differences occur within each fish taxon between sequential time frames.

326 After finding that no significant differences occur (SI 5, Table S2), we then grouped all pre-1775

327 (preindustrial) bins and compared this individually to all succeeding time periods (SI 5, Table

328 S3). For each bin, normality of distribution was first tested using a Shapiro-Wilk's test (SI 5,

329 Table S1). For datasets where all time periods were distributed normally, a one-way ANOVA

330 was used, and homogeneity of variance was assessed using a Levene's test. A post hoc Dunnett's

331 T3 test or a post hoc Tukey's HSD test was used to compare groups with variances that were

332 equal or unequal, respectively. For data sets where not all time periods were distributed

333 normally, Mann-Whitney U tests with Bonferroni corrected $\mathrm{p}$ values were used to compare 334 groups. 
Of the samples with sufficient collagen ( $n=607$ of 662 ) for isotopic analyses, $96 \%$ (total $n=582$ ) produced acceptable $\mathrm{C}: \mathrm{N}, \% \mathrm{C}$, and $\% \mathrm{~N}$ values satisfying quality control criteria. Interpretations also include previously published data from archaeological ( $n=68$; (Guiry, et al. 2016a; van der Merwe, et al. 2003)) and modern (post-1958 CE; $n=819$; (Colborne, et al. 2016; Fera, et al. 2017; Kiriluk, et al. 1995; Lumb and Johnson 2012; Mumby, et al. 2018; Rush, et al. 2012; Yuille, et al. 2015)) specimens. ZooMS analyses of 290 samples confirmed or helped to refine 244 nonspecies taxonomic identifications provided through bone morphology analyses by zooarchaeologists (it confirmed the identification for 225 of these 244 specimens and refined it to the level of species for the remaining 19). In a further 20 cases, specimens were reassigned to another taxon, namely, 12 to lake trout (Salvelinus namaycush) (previously assigned with varying degrees of confidence to the species or genus level in Salmo [ $n=8]$, Salvelinus [ $n=2]$, or Coregonus $[n=2]$ ); four to Atlantic salmon (Salmo salar) (previously identified with varying degrees of confidence as Salvelinus namaycush); four to whitefish (C. clupeaformis or C. artedi) (previously assigned with varying degrees of confidence to the species or genus level in Salmo salar $[\mathrm{n}=1]$, Salvelinus fontinalis $[\mathrm{n}=2]$, or Salvelinus namaycush $[\mathrm{n}=1])$. In 15 other cases, ZooMS could not reassign specimens (previously assigned with varying degrees of confidence to 352 the Salmonidae family level $[\mathrm{n}=3$ ] or to the species or genus level in Salmo [n=4], Salvelinus $353[n=1]$, or Coregonus $[n=4])$ to one of the four species and one genus used in this study. Based on 354 variation in peptide mass fingerprints, these samples likely derive from at least eleven other 355 species.

Stable nitrogen isotope compositions of bone and scale collagen from archaeological and 357 historical lake trout $(n=196)$, Atlantic salmon $(n=147)$, and whitefishes $(n=239)$ are summarized 
in the SI 5, Table S1 and presented in full in Figure 2 and SI 2. Given the large and well-dated sample $(n=1469)$ from archaeological sites $(n=42)$ and from museum-archived specimens and contemporary fisheries research $(n=<50$ locations) across a broad geographical range, we believe that the temporal trends observed in fish bone and scale collagen $\delta^{15} \mathrm{~N}$ are representative of processes occurring in Lake Ontario's open water ecosystem at a regional scale.

\section{$\underline{\text { Discussion and conclusion }}$}

1200-1830 CE: Fish $\delta^{15} \mathrm{~N}$ shows remarkably little variation between $1200 \mathrm{CE}$ and $1830 \mathrm{CE}$ (Figure 2), despite centuries of Indigenous and European land management in the Lake Ontario watershed, and provides a unique perspective on the long-term stability of a Great Lakes ecosystem. Prior to the nineteenth century, mean $\delta^{15} \mathrm{~N}$ values binned by taxon and at 100 -year intervals vary by less than $0.4 \%$ and show no statistically significant differences (SI 5, Tables S1 and S2). This long-term stasis, over at least 600 years, suggests that the nitrogen cycle and nitrogenous nutrient inputs for Lake Ontario were highly stable during the past millennium. Analyses of two additional Atlantic salmon specimens (not shown in Figure 2) from earlier archaeological deposits suggests that this stability extends further back in time to at least $900 \mathrm{CE}$. However, due to a paucity of samples from the earlier time period, discussion will focus on the post-1200 CE time frame. A comparison of mean $\delta^{15} \mathrm{~N}$ for pre-1800 bins ( $n=4$ see SI 5, Table S1) shows steady offsets between species: lake trout $+1.6 \pm 0.2 \%$ o Atlantic salmon $+1.3 \pm 0.2 \%$ > whitefishes. Replication of this pattern across all three taxa, encompassing multiple trophic levels, suggests that stability was also characteristic of interspecific trophic relationships throughout the broader pelagic food web during this period.

A wealth of historical and paleoenvironmental research on the Lake Ontario watershed (Beeton 1965; Bogue 2001; Estepp and Reavie 2015; Hodell and Schelske 1998; Jeffers, et al. 2015; 
Meyers 2003; Schelske and Hodell 1991b; Schelske and Hodell 1995; Schelske, et al. 1988; Schelske, et al. 1983; Wood 2000) provides an excellent opportunity to contextualize and consider the implications of this long-term stability. Proxies for past environmental conditions in other, smaller lakes in the same region document anthropogenic disturbances, at least as early as the thirteenth century CE, resulting from Indigenous land clearance and farming activities (e.g., Ekdahl, et al. 2004). These studies suggest that Indigenous land management practices, including the use of fire for forest clearance followed by crop cultivation (Munoz and Gajewski 2010), had a significant impact on soil erosion, sedimentation, and nutrient loading, causing early cultural eutrophication of aquatic environments in the region. European settlement of the Lake Ontario watershed began in the seventeenth century (Gentilcore 1984). Settlement expansion in the nineteenth century was accompanied by intensive commercial fishing (1800 onward; Bogue 2001), diversion of the Niagara River and work on the Erie and Welland canals (1820s; McIlwraith 1976; Wood 2000), broad-scale land clearance for lumber and agriculture (1840s1850s; Head 1975; Lower, et al. 1938), and wetland loss due to mining and other activities (1880s; Bogue 2001). Paleolimnological studies suggest that productivity of Lake Ontario's phytoplankton community began to grow slowly with the first European settlement, with more substantial impacts occurring in the mid-nineteenth century, probably in response to nutrient loading from soil erosion following deforestation (e.g., Estepp and Reavie 2015; Hodell, et al. 1998; Schelske 1991; SI 1). Despite clear historical and paleolimnological evidence for earlier anthropogenic impacts on nutrient dynamics (e.g., nitrogen and phosphorus loading, pollen species change) in other areas of the watershed (Bunting, et al. 1998; Duthie and Sreenivasa 1971; Ekdahl, et al. 2004; Ekdahl, et al. 2007; Munoz and Gajewski 2010; Schelske, et al. 1983; Yang, et al. 1993), archaeological fish stable nitrogen isotopic compositions demonstrate that 
404 Lake Ontario's nitrogen cycle and food web structure remained unchanged until the 1830s. In 405 that context, and given the sensitivity of aquatic nitrogen cycles to human disturbances 406 (Anderson and Cabana 2005; Botrel, et al. 2014; Lake, et al. 2001), these data underscore Lake 407 Ontario's stability throughout much of the last millennium and demonstrate a degree of 408 resilience at the level of the nitrogen cycle in large lake ecosystems to a variety of human 409 impacts, even when sustained over long time spans.

410 The resilience of Lake Ontario's nitrogen cycle has important implications for understanding 411 human impacts on freshwater ecosystems in the recent and more ancient past. It is now well 412 known that industrial activities over the past 150 years have fundamentally altered global 413 nutrient distributions and biogeochemical cycles (Galloway and Cowling 2002). Within the 414 context of debate about the onset of the Anthropocene (Lewis and Maslin 2015), there is a 415 growing consensus that "pristine environments" probably did not exist where humans were 416 present, because there was always some form of impact from human activities (Heckenberger, et 417 al. 2003). This perspective has been supported by archaeological research showing that ancient 418 societies, particularly those that used agriculture, had significant impacts at both local and 419 regional scales on terrestrial and aquatic nutrient cycles for millennia (Curtis, et al. 1998; Guiry, et al. 2018; Hadley, et al. 2010). Evaluating the role of past human activities as drivers of 421 ecological change has been a priority for archaeologists (Kintigh, et al. 2014), but is complicated 422 by the fact that ancient anthropogenic impacts on the environment are spatiotemporally 423 heterogeneous and occur along a continuum of intensity (from very significant to ephemeral). 424 For ecologists, this issue represents a source of uncertainty for retrospective studies where 425 archaeological or paleobiological information is not available to establish when and to what 426 extent past human activities have impacted a particular environment or biotic community 
427 (Holmes 2006; Lyman and Cannon 2004). In contrast to the cautionary tone of the debate about 428 the existence of "pristine" environments, our data demonstrate that, in fact, nutrient dynamics 429 and trophic relationships in larger aquatic environments can remain unchanged despite centuries 430 of moderate human land use.

431 Post-1830: Our analyses of archaeological and historical fish also show that this long-term 432 stability was profoundly altered when Lake Ontario's nutrient pools experienced an abrupt shift 433 in stable nitrogen isotope composition, becoming enriched in ${ }^{15} \mathrm{~N}$ throughout the pelagic 434 ecosystem. During the early to mid-nineteenth-century, fish $\delta^{15} \mathrm{~N}$ values underwent a 435 simultaneous, statistically significant elevation across multiple trophic levels, a difference that 436 has been sustained throughout the twentieth century and to this day (SI 4, Table S3). Atlantic 437 salmon, for instance, which had previously had a highly conserved distribution of $\delta^{15} \mathrm{~N}$ values, 438 show an elevation of $+3 \%$ in well-dated mid-nineteenth-century museum specimens. Although a 439 paucity of fish samples from the later nineteenth and early to mid-twentieth century precludes 440 detailed comparison, these data show similar overall trends (positive shifts between intraspecific $441 \quad \delta^{15} \mathrm{~N}$ means for pre-1800 and post-1990, ranging from $+5.3 \%$ to $+6.2 \%$, for all fish species) to 442 those observed in Lake Ontario's isotopic records from sediment cores $(+5.5 \%$ o to $+5.6 \%$ o for c. 4431850 to 1990s; Hodell and Schelske 1998; Figure 2). This further indicates that the observed 444 upward pattern in fish $\delta^{15} \mathrm{~N}$ predominately reflects a bottom-up shift in baseline $\delta^{15} \mathrm{~N}$ rather than 445 changes to fish trophic behavior.

446 It is nonetheless apparent from these data that human activities have resulted in meaningful 447 behavioral changes, including increased niche overlap between Lake Ontario's salmonid 448 communities. Prior to 1800 , there is minimal overlap between the $\delta^{15} \mathrm{~N}$ ranges for each species, 449 with overlaps of only $0.1 \%$ o between Atlantic salmon and whitefishes and only $0.9 \%$ between 
Atlantic salmon and lake trout over a 600-year period. In contrast, in the twentieth century, there is substantial overlap between $\delta^{15} \mathrm{~N}$ ranges for all species in all 25-year temporal bins (overlap ranges from 1.7 to $4.7 \%$ ). However, caution is required when interpreting trends in variation across time in this dataset. Differences in tissue turnover rates for sample materials between prenineteenth- (mainly collagen from bones - slow turnover) and twentieth-century (mainly previously published muscle from modern fish - fast turnover) time frames make detailed analysis of these trends difficult because tissues with faster turnover rates are inherently more likely to produce greater isotopic variation reflecting seasonal or other short-term dietary aberrations. With that caveat in mind, we argue that it is likely that the greater isotopic variation in twentieth-century specimens reflects changes in energy pathways and foraging behavior in response to major anthropogenic environmental disruptions (e.g., impacts from invasive species, extirpations, or over fishing; Bogue 2001; Colborne, et al. 2016; Dymond, et al. 2019; Fera, et al. 2017; Mills, et al. 2003).

The interspecific synchronicity and magnitude of this shift could have been caused by multiple related processes (Figure 3), including changes in the nitrogen cycle (at the phytoplankton-DIN pool level) favoring nitrogen transformations that retain ${ }^{15} \mathrm{~N}$ and changes in nitrogen inputs to the system that include ${ }^{15} \mathrm{~N}$-enriched nutrients (Finlay and Kendall 2007; Kendall 1998; Kendall, et al. 2007; Talbot 2001). Detailed historical and archaeological dating provides a robust temporal framework to evaluate which of these variables, and therefore what type of human activity, drove this initial ecosystem-wide ${ }^{15} \mathrm{~N}$ enrichment in Lake Ontario's food web. At archaeological sites with occupation dates as late as 1832, many fish show no sign of $\delta^{15} \mathrm{~N}$ elevation for their respective taxon, whereas a museum specimen dating from no later than 1857 shows significantly elevated $\delta^{15} \mathrm{~N}$ relative to the preceding centuries. In addition, many specimens from 
archaeological contexts with date ranges spanning this terminus ante quem (1832) and terminus post quem (1857) show elevated $\delta^{15} \mathrm{~N}$ values. These data therefore provide a temporal bracket for the initiation of change in Lake Ontario's nitrogen cycle, demonstrating that the shift occurred abruptly (within the context of the stability of the preceding 900 years), within a relatively short, 15-25-year window (1830s-1850s). This timeframe coincides precisely with the emergence of broad-scale land clearance for agriculture and timber harvesting in the Lake Ontario watershed. From the 1830s onward, especially around the middle of the century, historical analyses document how forestry activities, namely severe cutting as well as widespread burning of the remaining slash, radiated outward from the Lake Ontario waterfront to encompass much of the watershed. These forestry activities accelerated over time due to increased demand for timber (Head 1975) and cleared land, improved export capacity (canals and railroad; Lower, et al. 1938; McIlwraith 1976), and growing sawmill infrastructure (Head 1975; Wood 2000).

During this period, between the 1820 s and 1850s, the then-province of Upper Canada (which included the Ontario portion of the Lake Ontario watershed) had the fastest growing population in all of North America (Lewis 2001). Prior to 1830, newly settled farmers of European heritage focused on subsistence (Kelly 1973; Kelly 1975) and put considerable effort into clearing land for cultivation through cutting and burning (Ball 1979). However, relative to the mid-nineteenth century, these early farming activities were patchy, small in scale, and diversified in purpose, with most of the land granted to settlers remaining forested (Kelly 1975). Moreover, much of the land that was cleared retained stabilizing features of the previous forest, including stumps, root mats, and stones, for up to a decade, and sometimes much longer, while under cultivation and these would have mitigated issues with soil erosion and nutrient loss (Ball 1979; Kelly 1975). During this early period, in which the farmers were themselves clearing their land, care was 
often taken throughout the processes, from cutting trees to sowing crops (delaying ploughing), to further minimize soil nutrient loss (Ball 1979; Kelly 1971). As farms became established, however, stumps were removed, ploughs were more widely employed to break up the soil, and more land came under cultivation. Throughout the 1830s and 1840s, the agricultural system of Upper Canada was dominated by plough-intensive (three or more times per biennial fallow) and highly profitable monocropping of wheat (Kelly 1971; Kelly 1973). The focus on a wheatfallow-wheat agriculture system, as well as labor-saving furrow drainage and general avoidance of manure-based crop fertilization (until the 1850s) were widely blamed for rapid depletion of soil nutrients as well as erosion across the region (Kelly 1971; Kelly 1975). In this context, prior to the 1880 s, when a wider appreciation developed among farmers in the Lake Ontario watershed of the risks of higher runoff-to-percolation ratios that come with overly cleared lands, farmland was subjected to a damaging seasonal cycle of spring floods, washing away nutrient-rich organic materials, and summer droughts, parching what soil remained (Kelly 1975).

The isotopic composition of reactive forms of nitrogen in terrestrial ecosystems (i.e., soil nutrients including ammonia and nitrate), particularly those used for agriculture, is typically elevated relative to aquatic nitrogen sources (i.e., DIN) due to intense soil denitrification (Botrel, et al. 2014; Heaton 1986; Kendall 1998). In this context, the most parsimonious explanation for a broad-scale isotopic shift in Lake Ontario's nitrogen cycle is that there was an increase in ${ }^{15} \mathrm{~N}$ enriched nutrient inputs coming directly from soil erosion following deforestation during the 1840s in Lake Ontario's watershed area (Figure 3). This interpretation is supported by paleolimnological data (diatoms, sediment accumulation rates, and elemental and isotopic compositions of organic matter) from across the Lake Ontario watershed that records an uptick in nutrient loading from soil erosion runoff over the course of the mid-nineteenth century (Hodell 
and Schelske 1998). The relatively early timeframe for the observed shift in fish nitrogen isotopic compositions also suggests that its cause lay in new nutrient inputs originating primarily within the local watershed area, rather than from other Great Lakes, because upstream watersheds such as Lake Erie had not been as extensively settled by this time.

While inputs of ${ }^{15} \mathrm{~N}$-enriched terrestrial nutrients, released from eroding soils across the watershed, could easily result in the observed isotopic pattern, additional related processes, occurring both on land and in the water, could further contribute to the elevation of the stable nitrogen isotopic composition of Lake Ontario's biota (Figure 3). Higher soil erosion rates would increase mobilization of terrestrial nitrate across oxygen-poor ecotones (i.e., riparian/wetland zones), promoting bacterial denitrification, leaving the residual nutrients that are eventually delivered to Lake Ontario relatively enriched in ${ }^{15} \mathrm{~N}$ (Bowden 1987; Knowles 1982; McClain, et al. 2003). Increases in anthropogenic soil disturbance from farming and use of fertilizers (pushing the nitrogen cycle to be more open; Szpak 2014), as well as changes to $\mathrm{pH}$ in aquatic environments, may promote volatilization of ammonia before or during nutrient transport to Lake Ontario's food web (Kendall 1998). Increased phosphorous loading from soil runoff would also increase primary productivity, and the resulting bottom-up shift would have increased demand on Lake Ontario's pool of available reactive N, thereby reducing discrimination against

${ }^{15} \mathrm{~N}$ during assimilation of DIN by phytoplankton (Hodell and Schelske 1998). Regardless of which of these processes were most facilitative of the nitrogen isotopic patterning in Lake Ontario's fish community, the timing (between 1832 and 1857) and abruptness of the ecosystemwide shift indicates that the first human activity to have broad-scale impacts on nitrogenous nutrient pathways in the Great Lakes was likely deforestation. 
541 It is also worth noting that the time period covered by this study includes significant global 542 climatic fluctuations, including the Medieval Climate Anomaly (MCA; 950-1250 CE) and the 543 Little Ice Age (LIA; 1300-1850 CE). Paleolimnological studies of Lake Ontario (McFadden, et 544 al. 2005), Lake Erie (Finkelstein and Davis 2006), and other lakes in the local (Keizer, et al. 545 2015; Mullins, et al. 2011; Paquette and Gajewski 2013; Stager, et al. 2017) and broader region 546 (Laird, et al. 2012) show that climatic variability associated with both the MCA and LIA did 547 have some impact on aquatic and terrestrial environments across the Great Lakes and St. 548 Lawrence River region. For instance, evidence from flux in biogenic silica sedimentation rates 549 and changes in diatom (e.g., Fragelaria spp.) communities (Finkelstein, et al. 2005; McFadden, et al. 2005) demonstrates that these periods of climatic change were felt in the Lake Ontario 551 watershed over the past 1000 years. Climatic variability could affect Lake Ontario's nitrogen 552 cycle and the nitrogen isotopic composition of fish through changes in adjacent wetland size 553 (important sites for denitrification; Bowden 1987; McClain, et al. 2003), terrestrial runoff 554 impacts (Anderson and Cabana 2005; Heaton 1986), fluctuating dissolved oxygen levels 555 (controlling nitrification and denitrification rates; Knowles 1982), and changes to productivity 556 and thermally regulated stratification (seasonal draw-down of DIN; Hodell and Schelske 1998). Assuming that the influence of these potential sources of environmental variation did not cancel 558 one another out, our data suggest that late Holocene climatic variation did not influence Lake 559 Ontario's nitrogen cycle or trophic structure.

560 The temporal as well as taxonomical detail offered by isotopic data from archaeological fish 561 specimens has provided a framework for higher resolution interpretation of food web dynamics 562 as well as the timing and likely cause of the first human impacts on Lake Ontario's nitrogen 563 cycle. While previous isotopic analyses of organic matter from sediments (SI 1 and Figure 2; 
564 Hodell and Schelske 1998; McFadden, et al. 2004) have demonstrated that Lake Ontario's

565 nitrogenous nutrients were becoming ${ }^{15} \mathrm{~N}$ enriched during the nineteenth century, temporal

566 differences between datasets as well as a dearth of pre-1850 data prevented detailed analyses of

567 the processes which drove this change in lake-wide nitrogen cycling (SI 1). In addition, although

568 a variety of paleoenvironmental indicators (e.g., biogenic silica; Schelske 1991; Schelske and

569 Hodell 1991b; Schelske, et al. 1988) have shown human activities, such as deforestation, had

570 begun to have major nutrient (particularly P) loading impacts on the Lake Ontario watershed

571 from the mid-nineteenth century onward (although see, McAndrews and Boyko 1972; Schelske,

572 et al. 1983), our results demonstrate that Lake Ontario's nitrogen cycle had already been

573 substantially impacted decades earlier. Finally, by analyzing material from known taxa, we have

574 been able to document the impact that these changes in lake-wide nutrient dynamics had on long-

575 term food web structure.

Anthropological and Ecological Implications: This study is the first detailed analysis of longterm isotopic variation in freshwater fish. Results suggest that, by altering aquatic nutrient inputs, nineteenth-century European forestry practices in the lower Great Lakes region, whether focused on timber extraction or producing cleared land for agriculture, left a durable isotopic signature on fish in Lake Ontario. While the findings of this research focus on the Great Lakes watershed, the implications are global; human impacts on aquatic nutrient dynamics, particularly the nitrogen cycle, may be detectable in archaeological fish remains wherever land management has extensively modified the balance of nutrient exchange between local terrestrial and aquatic landscapes. Our results are particularly germane to recent discussion in conservation, calling for increased attention to how human impacts on land may be a driver of environmental deterioration in adjacent aquatic ecosystems (Abell 2002). For this reason, our findings have 
significant potential to serve as a model for research that seeks to understand fundamental changes in the way past societies, through forestry and other land management practices, affected aquatic nutrient dynamics around the globe (Jenny, et al. 2019).

With respect to debate on the origins of the Anthropocene, our results provide an important waypoint for the earliest lasting anthropogenic alteration of one of the world's great freshwater ecosystems. By identifying the tipping point at which human activities began to reorganize nutrient dynamics in the Great Lakes region, our results do not reveal a "golden spike" indictor for the starting point of the Anthropocene (Lewis and Maslin 2015), but, rather, provide a new signpost along the path of the global expansion of industrial impacts. These changes to Lake Ontario nonetheless represent a profound shift in the way humans have impacted the Great Lakes environment and illustrate some important anthropological and ecological considerations for how we can approach aquatic human-environment relationships in archaeology and historical ecology moving forward.

From an ecological perspective, an ecosystem-wide, bottom-up alteration of the nitrogen cycle of one of the world's largest freshwater environments over the course of only one or two decades, as shown here for Lake Ontario, demonstrates an unprecedented shift in the nature and scale of how humans cause environmental change. Understanding how humans have shaped earth's biological and physical systems remains an important archaeological and ecological challenge because finding lasting evidence of human impacts within complex regional or global systems is rare. This is particularly true for our understanding of ancient environmental nutrient dynamics, such as the cycling of nitrogen throughout an ecosystem, which, although fundamental to the success of human societies both today and in the past, preserves relatively few traces of change. Not only do our findings demonstrate how isotopic analyses of archaeological fauna can provide 
610 a clearer overview of ancient nutrient dynamics, they do so in one of the most enigmatic arenas

611 of human-environment interaction, namely, aquatic ecosystems. Even today, in comparison with

612 terrestrial environments, surprisingly little is known about how escalating human exploitation of

613 the world's aquatic environments will impact these vital ecosystems in the long term (Abell

614 2002). In that context, deeper retrospectives that are based on integrating results of contemporary

615 studies with data from both historical and archaeological resources, as demonstrated by this

616 study, have the potential to significantly enhance our understanding of the sensitivity of different

617 environments to human disturbances (Barak, et al. 2016; Dubois, et al. 2018; Jeffers, et al. 2015;

618 McLauchlan, et al. 2013).

619 From an anthropological perspective, approaching questions of human-environment interactions

620 from the vantage point of nutrient dynamics could provide a novel outlook on the role of humans

621 as drivers of ecological change. While the relationship between humans and their environment

622 has traditionally been framed against a backdrop of such factors as technological change and the

623 development of social complexity as sources of evidence for macro-scale exploitation of

624 environmental resources (Kintigh, et al. 2014), there is an increasing recognition that an

625 understanding of how humans have influenced their landscape at a molecular level can provide

626 powerful new lines of evidence for previously invisible but profound shifts in human-

627 environment relations (Guiry, et al. 2018). In particular, throughout most times and places in

628 human history, the carrying capacity of local terrestrial and aquatic ecosystems, which are the

629 environmental foundations upon which societies are sustained, has hinged on the maintenance of

630 well-balanced biogeochemical cycles and nutrient regimes. With respect to lake and other

631 freshwater ecosystems, which have been and continue to be of pivotal importance to many

632 cultures, it is possible to use isotopic analyses of local fauna to look back in time and pinpoint 
where, when, and in that context perhaps even how, human activities reached a turning point to become dominant drivers in their ecosystem.

Acknowledgments

Sampling permissions and logistical assistance: This analysis entailed destructive analysis of zooarchaeological specimens from Huron-Wendat and St. Lawrence Iroquoian sites. We thank representatives of descendant First Nations (Louis Lesage, Huron-Wendat Nation and Henry Lickers, Mohawk Council of Akwesasne) for permission for this analysis. We also thank Hernan Lopez-Fernandez and the Royal Ontario Museum; Shari Prowse and the Ministry of Tourism, Culture and Sport; Ron Williamson, Alexis Dunlop, Caitlin Coleman and Archaeological Services Inc.; Dena Doroszenko and the Ontario Heritage Trust; Shaun Austin and Wood Environment \& Infrastructure Solutions; Stacey Girling-Christie, Jean-Luc Pilon and the Canadian Museum of History; Jennifer Campbell, Meaghan Eckersley and the City of Kingston; Lena Beliveau, Ashley Mendes and the Royal Military College; Loren Scott, Cassandra Hamilton, Janet Batchelor and the Toronto Region Conservation Authority; David G. Smith, Heather M.-L. Miller and the Department of Anthropology, University of Toronto Mississauga; Andrew Martindale and Jessica Metcalf, University of British Columbia. Funding: Department of Anthropology, University of British Columbia; Social Sciences and Humanities Research Council of Canada (SSHRC) Insight Development Grant. EG was supported by a SSHRC Postdoctoral Research Fellowship, a SSHRC Banting Postdoctoral Research Fellowship, and the Department of Anthropology at the University of British Columbia. MB was supported by a Royal Society University Research Fellowship. Author Contributions: E.G. designed research. S.N.-H., A.H., T.O., E.H., and E.G. contributed samples for analysis. E.G., M.B., P.S. performed isotopic, ZooMS, and statistical analyses, respectively. E.G. interpreted results and wrote the paper with assistance from all authors. Figures were created by A.H. (1) and E.G. (2 and 3). Competing Interests: The authors declare no competing interests. Data Accessibility: All data generated as part of this research is available in the SI. We thank two anonymous reviewers for their helpful comments. 


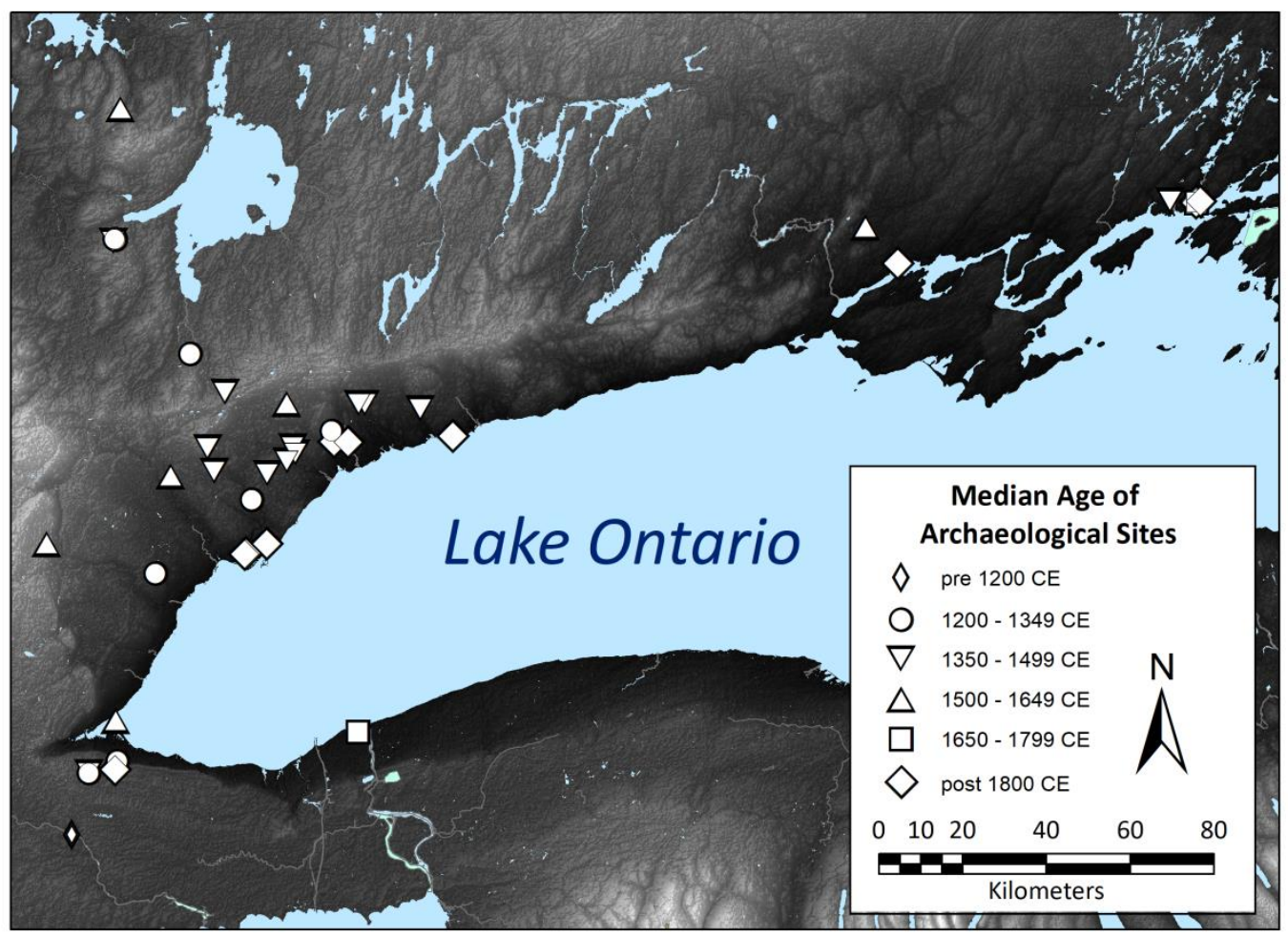

662

663 Figure 1. Map of study area showing locations of archaeological sites from which fish bone 664 samples were collected. Map data from NASA and ESRI.

665 


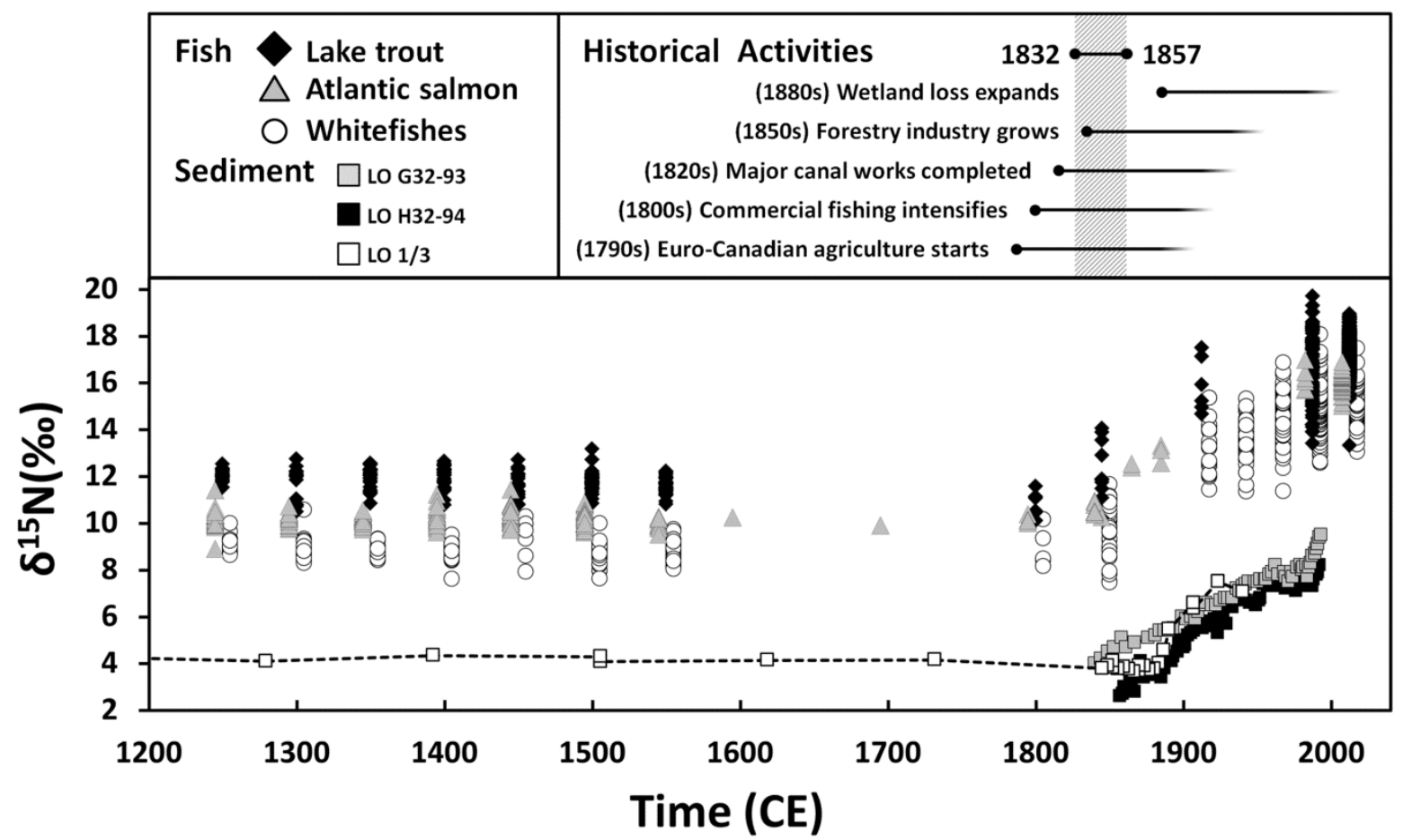

666

667

668

669

670

671

672

673

Figure 2. Stable nitrogen isotope values for fish $(n=1469)$ versus time. Data are binned by 50 -

year (archaeological) and 25-year (historical/modern) intervals. For fish data sourced from the

literature (Colborne, et al. 2016; Fera, et al. 2017; Guiry, et al. 2016a; Kiriluk, et al. 1995; Lumb and Johnson 2012; Mumby, et al. 2018; Rush, et al. 2012; van der Merwe, et al. 2003; Yuille, et al. 2015). For sediment data sourced from the literature: LO G32-93, LO H32-94 (Hodell and Schelske 1998), and LO 1/3 (McFadden, et al. 2004). 


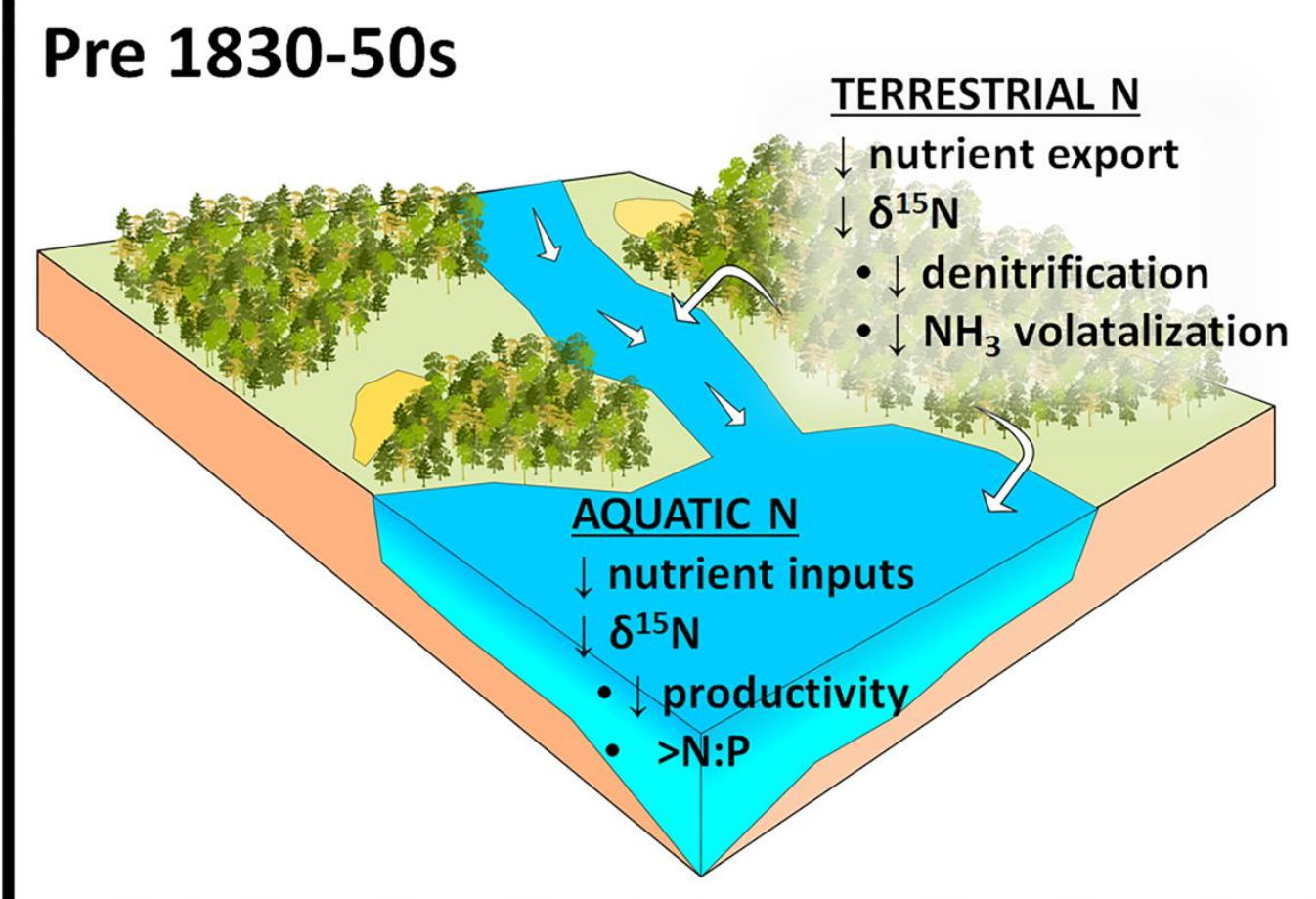

\section{Post 1830-50s}

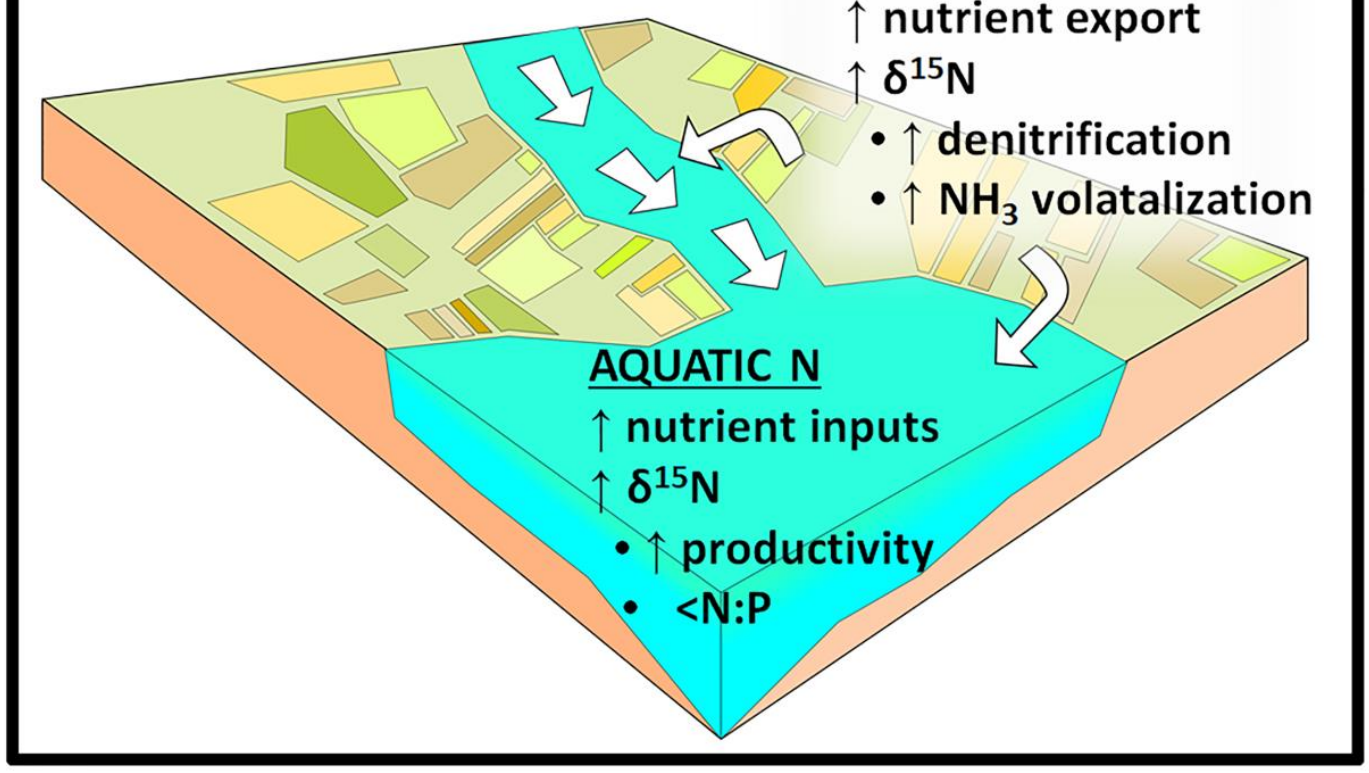

\section{TERRESTRIAL N}

$\uparrow$ nutrient export $\delta^{15} \mathrm{~N}$

$\uparrow$ denitrification

- $\uparrow \mathrm{NH}_{3}$ volatalization

675 Figure 3. Schematic diagram of nutrient regime shifts (nitrogen sources and isotopic

676 compositions) that could be associated with the intensification of deforestation and agriculture in 677 the Lake Ontario watershed during the early to mid-nineteenth century. 
$\underline{\text { Supplementary Information }}$

SI1 Paleoenvironmental context

SI2 Isotopic results

SI3 Calibration and analytical uncertainty

SI4 Collagen peptide finger-printing results

SI5 Statistical results

\section{$\underline{\text { References }}$}

Abell R. 2002. Conservation biology for the biodiversity crisis: a freshwater follow-up. Conservation Biology 16(5):1435-1437.

Allan JD, McIntyre PB, Smith SDP, Halpern BS, Boyer GL, Buchsbaum A, Burton GA, Campbell LM, Chadderton WL, Ciborowski JJH and others. 2013. Joint analysis of Stressors and ecosystem services to enhance restoration effectiveness. Proceedings of the National Academy of Sciences of the United States of America 110(1):372-377.

Anas MUM, Simpson GL, Leavitt PR, Cumming BF, Laird KR, Scott KA, Das B, Wolfe JD, Hesjedal B, Mushet GR and others. 2019. Taxon-specific variation in $\delta 13 \mathrm{C}$ and $\delta 15 \mathrm{~N}$ of subfossil invertebrate remains: Insights into historical trophodynamics in lake food-webs. Ecological Indicators 102:834-847.

Anderson C, Cabana G. 2005. $\delta 15 \mathrm{~N}$ in riverine food webs: effects of $\mathrm{N}$ inputs from agricultural watersheds. Canadian Journal of Fisheries and Aquatic Sciences 62(2):333-340.

Anderson NJ. 2014. Landscape disturbance and lake response: temporal and spatial perspectives. Freshwater Reviews 7(2):77-120.

Ball NR. 1979. The technology of settlement and land clearing in Upper Canada prior to 1840: University of Toronto.

Barak RS, Hipp AL, Cavender-Bares J, Pearse WD, Hotchkiss SC, Lynch EA, Callaway JC, Calcote R, Larkin DJ. 2016. Taking the long view: integrating recorded, archeological, paleoecological, and evolutionary data into ecological restoration. International Journal of Plant Sciences 177(1):90-102.

Beeton AM. 1965. Eutrophication of the St. Lawrence great lakes. Limnology and Oceanography $10(2): 240-254$.

Bogue MB. 2001. Fishing the Great Lakes: an environmental history, 1783-1933: Univ of Wisconsin Press.

Botrel M, Gregory-Eaves I, Maranger R. 2014. Defining drivers of nitrogen stable isotopes $(\delta 15 N)$ of surface sediments in temperate lakes. Journal of Paleolimnology 52(4):419433.

Bowden WB. 1987. The biogeochemistry of nitrogen in freshwater wetlands. Biogeochemistry 4(3):313-348. 
Buckley M, Collins M, Thomas- Oates J, Wilson JC. 2009. Species identification by analysis of bone collagen using matrix- assisted laser desorption/ionisation time- of- flight mass spectrometry. Rapid communications in mass spectrometry 23(23):3843-3854.

Buckley M, Gu M, Herman J, Junno J-A, Denys C, Chamberlain AT. 2018. Species identification of voles and lemmings from Late Pleistocene deposits in Pin Hole Cave (Creswell Crags, UK) using collagen fingerprinting. Quaternary international 483:83-89.

Bump JK, Fox-Dobbs K, Bada JL, Koch PL, Peterson RO, Vucetich JA. 2007. Stable isotopes, ecological integration and environmental change: wolves record atmospheric carbon isotope trend better than tree rings. Proceedings of the Royal Society of London B: Biological Sciences 274(1624):2471-2480.

Bunting MJ, Morgan CR, Bakel MV, Warner BG. 1998. Pre-European settlement conditions and human disturbance of a coniferous swamp in southern Ontario. Canadian Journal of Botany 76(10): 1770-1779.

Canfield DE, Glazer AN, Falkowski PG. 2010. The evolution and future of Earth's nitrogen cycle. science 330(6001):192-196.

Colborne SF, Rush SA, Paterson G, Johnson TB, Lantry BF, Fisk AT. 2016. Estimates of lake trout (Salvelinus namaycush) diet in Lake Ontario using two and three isotope mixing models. Journal of Great Lakes Research 42(3):695-702.

Collister JW, Hayes J. 1991. A preliminary study of the carbon and nitrogen isotopic biogeochemistry of lacustrine sedimentary rocks from the Green River Formation, Wyoming, Utah, and Colorado.

Curtis JH, Brenner M, Hodell DA, Balser RA, Islebe GA, Hooghiemstra H. 1998. A multi-proxy study of Holocene environmental change in the Maya Lowlands of Peten, Guatemala. Journal of paleolimnology 19(2):139-159.

DeNiro MJ. 1985. Postmortem preservation and alteration of in vivo bone collagen isotope ratios in relation to palaeodietary reconstruction. Nature 317:806-809.

Denk TR, Mohn J, Decock C, Lewicka-Szczebak D, Harris E, Butterbach-Bahl K, Kiese R, Wolf B. 2017. The nitrogen cycle: A review of isotope effects and isotope modeling approaches. Soil Biology and Biochemistry 105:121-137.

Dubois N, Saulnier-Talbot É, Mills K, Gell P, Battarbee R, Bennion H, Chawchai S, Dong X, Francus P, Flower R. 2018. First human impacts and responses of aquatic systems: A review of palaeolimnological records from around the world. The Anthropocene Review 5(1):28-68.

Duthie HC, Sreenivasa M. 1971. Evidence for the eutrophication of Lake Ontario from the sedimentary diatom succession. In: Duthie HC, Yang, J.R., Edwards, editor. Proceedings, 14th Conference on Great Lakes Research. Ann Arbor, Michigan: International Association for Great Lakes Research. p 1-13.

Dymond JR, MacKay HH, Burridge ME, Holm E, Bird PW. 2019. The history of the Atlantic Salmon in Lake Ontario. Aquatic Ecosystem Health \& Management(just-accepted):1-12.

Ekdahl EJ, Teranes JL, Guilderson TP, Turton CL, McAndrews JH, Wittkop CA, Stoermer EF. 2004. Prehistorical record of cultural eutrophication from Crawford Lake, Canada. Geology 32(9):745-748.

Ekdahl EJ, Teranes JL, Wittkop CA, Stoermer EF, Reavie ED, Smol JP. 2007. Diatom assemblage response to Iroquoian and Euro-Canadian eutrophication of Crawford Lake, Ontario, Canada. Journal of Paleolimnology 37(2):233-246. 
Estepp LR, Reavie ED. 2015. The ecological history of Lake Ontario according to phytoplankton. Journal of Great Lakes Research 41(3):669-687.

Fera SA, Rennie MD, Dunlop ES. 2017. Broad shifts in the resource use of a commercially harvested fish following the invasion of dreissenid mussels. Ecology 98(6):1681-1692.

Finkelstein SA, Davis AM. 2006. Paleoenvironmental records of water level and climatic changes from the middle to late Holocene at a Lake Erie coastal wetland, Ontario, Canada. Quaternary Research 65(1):33-43.

Finkelstein SA, Peros MC, Davis AM. 2005. Late Holocene paleoenvironmental change in a Great Lakes coastal wetland: integrating pollen and diatom datasets. Journal of Paleolimnology 33(1):1-12.

Finlay JC, Kendall C. 2007. Stable isotope tracing of temporal and spatial variability in organic matter sources to freshwater ecosystems. Stable isotopes in ecology and environmental science 2:283-333.

Frossard V, Verneaux V, Millet L, Jenny JP, Arnaud F, Magny M, Perga ME. 2014. Reconstructing long- term changes (150 years) in the carbon cycle of a clear- water lake based on the stable carbon isotope composition ( $\delta 13 \mathrm{C})$ of chironomid and cladoceran subfossil remains. Freshwater biology 59(4):789-802.

Galloway JN, Cowling EB. 2002. Reactive nitrogen and the world: 200 years of change. AMBIO: A Journal of the Human Environment 31(2):64-71.

Gentilcore RL. 1984. The making of a province: Ontario to 1850. American Review of Canadian Studies 14(2):137-156.

Gruber N, Galloway JN. 2008. An Earth-system perspective of the global nitrogen cycle. Nature 451(7176):293.

Gu B. 2009. Variations and controls of nitrogen stable isotopes in particulate organic matter of lakes. Oecologia 160(3):421-431.

Guiry E. 2019. Complexities of Stable Carbon and Nitrogen Isotope Biogeochemistry in Ancient Freshwater Ecosystems: Implications for the Study of Past Subsistence and Environmental Change. Frontiers in Ecology and Evolution 7(313).

Guiry EJ, Beglane F, Szpak P, Schulting R, McCormick F, Richards MP. 2018. Anthropogenic changes to the Holocene nitrogen cycle in Ireland. Science Advances 4(6).

Guiry EJ, Needs-Howarth S, Friedland KD, Hawkins AL, Szpak P, Macdonald R, Courtemanche M, Holm E, Richards MP. 2016a. Lake Ontario salmon (Salmo salar) were not migratory: a long-standing historical debate solved through stable isotope analysis. Scientific Reports 6.

Guiry EJ, Szpak P, Richards MP. 2016b. Effects of lipid extraction and ultrafiltration on stable carbon and nitrogen isotopic compositions of fish bone collagen. Rapid Communications in Mass Spectrometry 30(13):1591-1600.

Hadley KR, Douglas MS, Blais JM, Smol JP. 2010. Nutrient enrichment in the High Arctic associated with Thule Inuit whalers: a paleolimnological investigation from Ellesmere Island (Nunavut, Canada). Hydrobiologia 649(1):129-138.

Hawkins AL, Needs-Howarth S, Orchard TJ, Guiry EJ. 2019. Beyond the local fishing hole: A preliminary study of pan-regional fishing in southern Ontario (ca. $1000 \mathrm{CE}$ to $1750 \mathrm{CE}$ ). Journal of Archaeological Science: Reports 24:856-868.

Head CG. 1975. Introduction to forest exploitation in nineteenth-century Ontario. In: Wood JD, editor. Perspectives on Landscape and Settlement in Nineteenth-Century Ontario: McGill-Queen's Press-MQUP. p 78-112. 
Heaton TH. 1986. Isotopic studies of nitrogen pollution in the hydrosphere and atmosphere: a review. Chemical Geology: Isotope Geoscience Section 59:87-102.

Heckenberger MJ, Kuikuro A, Kuikuro UT, Russell JC, Schmidt M, Fausto C, Franchetto B. 2003. Amazonia 1492: pristine forest or cultural parkland? Science 301(5640):17101714.

Hobson KA, Clark RG. 1992. Assessing Avian Diets Using Stable Isotopes I: Turnover of 13C in Tissues. The Condor 94(1):181-188.

Hodell DA, Schelske CL. 1998. Production, sedimentation, and isotopic composition of organic matter in Lake Ontario. Limnology and Oceanography 43(2):200-214.

Hodell DA, Schelske CL, Fahnenstiel GL, Robbins LL. 1998. Biologically induced calcite and its isotopic composition in Lake Ontario. Limnology and Oceanography 43(2):187-199.

Hoffman JC, Kelly JR, Peterson GS, Cotter AM, Starry MA, Sierszen ME. 2012. Using $\delta 15 \mathrm{~N}$ in fish larvae as an indicator of watershed sources of anthropogenic nitrogen: response at multiple spatial scales. Estuaries and coasts 35(6):1453-1467.

Holm E, Mandrak NE, Burridge ME. 2009. The ROM field guide to freshwater fishes of Ontario. Toronto: Royal Ontario Museum.

Holmes NT. 2006. The importance of long- term data sets in science and river management. Aquatic Conservation: Marine and Freshwater Ecosystems 16(4):329-333.

Humphries P, Winemiller KO. 2009. Historical impacts on river fauna, shifting baselines, and challenges for restoration. BioScience 59(8):673-684.

Jeffers ES, Nogué S, Willis KJ. 2015. The role of palaeoecological records in assessing ecosystem services. Quaternary Science Reviews 112:17-32.

Jenny J-P, Koirala S, Gregory-Eaves I, Francus P, Niemann C, Ahrens B, Brovkin V, Baud A, Ojala AEK, Normandeau A and others. 2019. Human and climate global-scale imprint on sediment transfer during the Holocene. Proceedings of the National Academy of Sciences 116(46):22972-22976.

Keizer PS, Gajewski K, McLeman R. 2015. Forest dynamics in relation to multi-decadal lateHolocene climatic variability, eastern Ontario, Canada. Review of Palaeobotany and Palynology 219:106-115.

Kelly K. 1971. Wheat farming in Simcoe county in the mid-nineteenth century. Canadian Geographer 15(2):95-112.

Kelly K. 1973. Notes on a type of mixed farming practised in Ontario during the early nineteenth century. Canadian Geographer/Le Géographe canadien 17(3):205-219.

Kelly K. 1975. The impact of nineteenth-century agricultural settlement on the land. In: Wood JD, editor. Perspectives on Landscape and Settlement in Nineteenth-Century Ontario. Ottawa: McClelland and Stewart. p 64-77.

Kendall C. 1998. Tracing nitrogen sources and cycling in catchments. Isotope tracers in catchment hydrology: Elsevier. p 519-576.

Kendall C, Elliott EM, Wankel SD. 2007. Tracing anthropogenic inputs of nitrogen to ecosystems. Stable isotopes in ecology and environmental science 2:375-449.

Kintigh KW, Altschul JH, Beaudry MC, Drennan RD, Kinzig AP, Kohler TA, Limp WF, Maschner HD, Michener WK, Pauketat TR. 2014. Grand challenges for archaeology. American Antiquity 79(1):5-24.

Kiriluk RM, Servos MR, Whittle DM, Cabana G, Rasmussen JB. 1995. Using ratios of stable nitrogen and carbon isotopes to characterize the biomagnification of DDE, mirex, and 
PCB in a Lake Ontario pelagic food web. Canadian Journal of Fisheries and Aquatic Sciences 52(12):2660-2674.

Knowles R. 1982. Denitrification. Microbiological reviews 46(1):43.

Laird KR, Haig HA, Ma S, Kingsbury MV, Brown TA, Lewis C, Oglesby RJ, Cumming BF. 2012. Expanded spatial extent of the Medieval Climate Anomaly revealed in lakesediment records across the boreal region in northwest Ontario. Global change biology 18(9):2869-2881.

Lake JL, McKinney RA, Osterman FA, Pruell RJ, Kiddon J, Ryba SA, Libby AD. 2001. Stable nitrogen isotopes as indicators of anthropogenic activities in small freshwater systems. Canadian Journal of Fisheries and Aquatic Sciences 58(5):870-878.

Lean D, Knowles R. 1987. Nitrogen transformations in Lake Ontario. Canadian Journal of Fisheries and Aquatic Sciences 44(12):2133-2143.

Leggett M, Johannsson O, Hesslein R, Dixon D, Taylor W, Servos M. 2000. Influence of inorganic nitrogen cycling on the $\delta 15 \mathrm{~N}$ of Lake Ontario biota. Canadian Journal of Fisheries and Aquatic Sciences 57(7):1489-1496.

Lewis FD. 2001. Farm settlement with imperfect capital markets: a life- cycle application to Upper Canada, 1826-1851. Canadian Journal of Economics 34(1):174-195.

Lewis SL, Maslin MA. 2015. Defining the anthropocene. Nature 519(7542):171-180.

Lower ARM, Carrothers WA, Saunders SA. 1938. The North American assault on the Canadian forest: a history of the lumber trade between Canada and the United States: Toronto, The Ryerson Press; New Haven, Yale University Press;[etc., etc.] for the Carnegie Endowment for International Peace, Division of Economics and History.

Lu Y, Meyers PA, Johengen TH, Eadie BJ, Robbins JA, Han H. 2010. $\delta 15$ N values in Lake Erie sediments as indicators of nitrogen biogeochemical dynamics during cultural eutrophication. Chemical Geology 273(1):1-7.

Lu YH, Meyers PA, Robbins JA, Eadie BJ, Hawley N, Ji KH. 2014. Sensitivity of sediment geochemical proxies to coring location and corer type in a large lake: Implications for paleolimnological reconstruction. Geochemistry, Geophysics, Geosystems 15(5):19601976.

Lumb CE, Johnson TB. 2012. Retrospective growth analysis of lake whitefish (Coregonus clupeaformis) in Lakes Erie and Ontario, 1954-2003. Advances in Limnology:429-454.

Lyman RL, Cannon KP. 2004. Zooarchaeology and conservation biology: University of Utah Press.

McAndrews J, Boyko M. Dating recent sediment in Lake Ontario by correlation with a varvedated pollen diagram; 1972. p 1265-1274.

McClain ME, Boyer EW, Dent CL, Gergel SE, Grimm NB, Groffman PM, Hart SC, Harvey JW, Johnston CA, Mayorga E. 2003. Biogeochemical hot spots and hot moments at the interface of terrestrial and aquatic ecosystems. Ecosystems 6(4):301-312.

McFadden MA, Mullins HT, Patterson WP, Anderson WT. 2004. Paleoproductivity of eastern Lake Ontario over the past 10,000 years. Limnology and Oceanography 49(5):15701581.

McFadden MA, Patterson WP, Mullins HT, Anderson WT. 2005. Multi-proxy approach to longand short-term Holocene climate-change: evidence from eastern Lake Ontario. Journal of Paleolimnology 33(3):371-391.

McIlwraith TF. 1976. Freight capacity and utilization of the Erie and Great Lakes canals before 1850. The Journal of Economic History 36(4):852-877. 
McLauchlan KK, Williams JJ, Engstrom DR. 2013. Nutrient cycling in the palaeorecord: Fluxes from terrestrial to aquatic ecosystems. The Holocene 23(11):1635-1643.

Meyers PA. 2003. Applications of organic geochemistry to paleolimnological reconstructions: a summary of examples from the Laurentian Great Lakes. Organic geochemistry 34(2):261-289.

Mills E, Casselman J, Dermott R, Fitzsimons J, Gal G, Holeck K, Hoyle J, Johannsson O, Lantry B, Makarewicz J. 2003. Lake Ontario: food web dynamics in a changing ecosystem (1970-2000). Canadian Journal of Fisheries and Aquatic Sciences 60(4):471-490.

Morrissey CA, Boldt A, Mapstone A, Newton J, Ormerod SJ. 2013. Stable isotopes as indicators of wastewater effects on the macroinvertebrates of urban rivers. Hydrobiologia 700(1):231-244.

Mullins HT, Patterson WP, Teece MA, Burnett AW. 2011. Holocene climate and environmental change in central New York (USA). Journal of Paleolimnology 45(2):243-256.

Mumby JA, Larocque SM, Johnson TB, Stewart TJ, Fitzsimons JD, Weidel BC, Walsh MG, Lantry JR, Yuille MJ, Fisk AT. 2018. Diet and trophic niche space and overlap of Lake Ontario salmonid species using stable isotopes and stomach contents. Journal of Great Lakes Research 44(6):1383-1392.

Munoz SE, Gajewski K. 2010. Distinguishing prehistoric human influence on late-Holocene forests in southern Ontario, Canada. The Holocene 20(6):967-981.

Paquette N, Gajewski K. 2013. Climatic change causes abrupt changes in forest composition, inferred from a high-resolution pollen record, southwestern Quebec, Canada. Quaternary Science Reviews 75:169-180.

Pennock JR, Velinsky DJ, Ludlam JM, Sharp JH, Fogel ML. 1996. Isotopic fractionation of ammonium and nitrate during uptake by Skeletonema costatum: Implications for $\delta 15 \mathrm{~N}$ dynamics under bloom conditions. Limnology and Oceanography 41(3):451-459.

Perga M-E. 2010. Potential of $\delta 13 \mathrm{C}$ and $\delta 15 \mathrm{~N}$ of cladoceran subfossil exoskeletons for paleoecological studies. Journal of Paleolimnology 44(2):387-395.

Perga ME, Desmet M, Enters D, Reyss JL. 2010. A century of bottom-up-and top-down-driven changes on a lake planktonic food web: A paleoecological and paleoisotopic study of Lake Annecy, France. Limnology and Oceanography 55(2):803-816.

Post DM. 2002. Using stable isotopes to estimate trophic position: models, methods, and assumptions. Ecology 83(3):703-718.

Rush SA, Paterson G, Johnson TB, Drouillard KG, Haffner GD, Hebert CE, Arts MT, McGoldrick DJ, Backus SM, Lantry BF. 2012. Long- term impacts of invasive species on a native top predator in a large lake system. Freshwater Biology 57(11):2342-2355.

Schelske CL. 1991. Historical nutrient enrichment of Lake Ontario: paleolimnological evidence. Canadian Journal of Fisheries and Aquatic Sciences 48(8):1529-1538.

Schelske CL, Hodell DA. 1991a. Recent changes in productivity and climate of Lake Ontario detected by isotopic analysis of sediments. Limnology and Oceanography 36(5):961-975.

Schelske CL, Hodell DA. 1991b. Recent changes in productivity and climate of Lake Ontario detected by isotopic analysis of sediments. Limnology and Oceanography 36(3):961-975.

Schelske CL, Hodell DA. 1995. Using carbon isotopes of bulk sedimentary organic matter to reconstruct the history of nutrient loading and eutrophication in Lake Erie. Limnology and Oceanography 40(5):918-929. 
Schelske CL, Robbins JA, Gardner WS, Conley DJ, Bourbonniere RA. 1988. Sediment record of biogeochemical responses to anthropogenic perturbations of nutrient cycles in Lake Ontario. Canadian Journal of Fisheries and Aquatic Sciences 45(7):1291-1303.

Schelske CL, Stoermer EF, Conley DJ, Robbins JA, Glover RM. 1983. Early Eutrophication in the Lower Great Lakes: New Evidence from Biogenic Silica in Sediments. Science 222(4621):320-322.

Schilder J, van Hardenbroek M, Bodelier P, Kirilova EP, Leuenberger M, Lotter AF, Heiri O. 2017. Trophic state changes can affect the importance of methane-derived carbon in aquatic food webs. Proceedings of the Royal Society B: Biological Sciences 284(1857):20170278.

Schindler DW, Dillon PJ, Schreier H. 2006. A review of anthropogenic sources of nitrogen and their effects on Canadian aquatic ecosystems. Biogeochemistry 79(1-2):25-44.

Sebilo M, Billen G, Mayer B, Billiou D, Grably M, Garnier J, Mariotti A. 2006. Assessing nitrification and denitrification in the Seine River and estuary using chemical and isotopic techniques. Ecosystems 9(4):564-577.

Smith VH, Schindler DW. 2009. Eutrophication science: where do we go from here? Trends in Ecology \& Evolution 24(4):201-207.

Stager JC, Cumming BF, Laird KR, Garrigan-Piela A, Pederson N, Wiltse B, Lane CS, Nester J, Ruzmaikin A. 2017. A 1600-year diatom record of hydroclimate variability from Wolf Lake, New York. The Holocene 27(2):246-257.

Sterner RW, Ostrom P, Ostrom NE, Klump JV, Steinman AD, Dreelin EA, Vander Zanden MJ, Fisk AT. 2017. Grand challenges for research in the Laurentian Great Lakes. Limnology and Oceanography 62(6):2510-2523.

Stewart TJ, Rudstam L, Watkins J, Johnson TB, Weidel B, Koops MA. 2016. Research needs to better understand Lake Ontario ecosystem function: A workshop summary. Journal of Great Lakes Research 42(1):1-5.

Szpak P. 2011. Fish bone chemistry and ultrastructure: implications for taphonomy and stable isotope analysis. Journal of Archaeological Science 38(12):3358-3372.

Szpak P. 2014. Complexities of nitrogen isotope biogeochemistry in plant-soil systems: implications for the study of ancient agricultural and animal management practices. Frontiers in plant science 5.

Szpak P, Buckley M, Darwent CM, Richards MP. 2018. Long- term ecological changes in marine mammals driven by recent warming in northwestern Alaska. Global change biology 24(1):490-503.

Szpak P, Krippner K, Richards M. 2017a. Effects of Sodium Hydroxide Treatment and Ultrafiltration on the Removal of Humic Contaminants from Archaeological Bone. International Journal of Osteoarchaeology 27(6):1070-1077.

Szpak P, Metcalfe JZ, Macdonald RA. 2017b. Best practices for calibrating and reporting stable isotope measurements in archaeology. Journal of Archaeological Science: Reports 13:609-616.

Talbot MR. 2001. Nitrogen Isotopes in Palaeolimnology. In: Last WM, Smol JP, editors. Tracking Environmental Change Using Lake Sediments: Physical and Geochemical Methods. Dordrecht: Springer Netherlands. p 401-439.

Trueman CN, Moore A. 2007. Use of the stable isotope composition of fish scales for monitoring aquatic ecosystems. Terrestrial Ecology 1:145-161. 
van der Merwe NJ, Williamson RF, Pfeiffer S, Thomas SC, Allegretto KO. 2003. The Moatfield ossuary: isotopic dietary analysis of an Iroquoian community, using dental tissue. Journal of Anthropological Archaeology 22(3):245-261.

van Hardenbroek M, Heiri O, Grey J, Bodelier PL, Verbruggen F, Lotter AF. 2010. Fossil chironomid $\delta 13 \mathrm{C}$ as a proxy for past methanogenic contribution to benthic food webs in lakes? Journal of Paleolimnology 43(2):235-245.

Warrick G. 2008. A population history of the Huron-Petun, AD 500-1650. Cambridge, UK: Cambridge University Press.

Williamson RF. 2014. The Archaeological History of the Wendat to AD 1651: An Overview. Ontario Archaeology 94:3-64.

Wood D. 2000. Making Ontario: McGill-Queen's Press-MQUP.

Yang J-R, Duthie HC, Delorme LD. 1993. Reconstruction of the recent environmental history of Hamilton Harbour (Lake Ontario, Canada) from analysis of siliceous microfossils. Journal of Great Lakes Research 19(1):55-71.

Yuille MJ, Fisk AT, Stewart T, Johnson TB. 2015. Evaluation of Lake Ontario salmonid niche space overlap using stable isotopes. Journal of Great Lakes Research 41(3):934-940. 